\title{
the third subject position
}

\author{
marjan simenc ${ }^{1}$ \\ university of ljubljana; slovenia
}

\section{abstract}

The article refers to Biesta's distinction between two subject positions that are related to what philosophy with children (PWC) is and what it could be. The author attempts to demonstrate - by referring to a different philosophical practice, the philosophy café - that a third subject position can be found in the existing practice of PWC. Two forms of this practice could be described as the argumentative and the hermeneutic approach to conducting a philosophical dialogue. The argumentative interpretation considers the philosophical element of philosophy cafés to lie in following the philosophical method which is determined by three fundamental philosophical competences. What is characteristic of the third subject position is subject's embeddedness in the world which changes the world itself. This is no longer a world observed by the subject from a distance but a world which essentially determines the subject. Even though this third subject position could arguably be derived from the first one, it is nevertheless relevant for reflections on PWC. On the one hand, it highlights the diversity and complexity of existing practices of PWC; on the other, it raises the question of the relationship between the first and second subject positions by addressing the meaning of the concept of the world.

keywords: philosophy with children; subject position; world; knowledge.

\section{a posição do terceiro sujeito}

resumo

Este artigo se refere à distinção feita por Biesta entre duas posições do sujeito, que estão relacionadas ao que a Filosofia com Crianças é e o que ela pode ser. $\mathrm{O}$ autor do presente texto tenta demonstrar - referindo-se a uma prática filosófica diferente, o café filosófico que uma terceira posição do sujeito pode ser encontrada nas práticas existentes de Filosofia com Crianças. Duas formas desta prática podem ser descritas como sendo as perspectivas argumentativa e hermenêutica de conduzir o diálogo filosófico. A interpretação argumentativa considera o elemento filosófico dos cafés filosóficos como baseando-se no método filosófico que é determinado por três competências filosóficas fundamentais. O que é característico da posição do terceiro sujeito é a inclusão do sujeito no mundo que muda o próprio mundo. Este não é mais um mundo observado à distância pelo sujeito, mas um mundo que determina essencialmente o sujeito. Apesar da posição do terceiro sujeito poder ser defendida como derivada da primeira, ela é ainda assim relevante às reflexões sobre a Filosofia com Crianças. Por um lado, ela destaca a diversidade e complexidade das práticas existentes em Filosofia com Crianças; por outro lado, ela levanta a questão da relação entre as posições de primeiro e segundo sujeito, por se referir ao significado do próprio conceito de mundo.

palavras-chave: filosofia com crianças; posição do sujeito; conhecimento.

\footnotetext{
${ }^{1}$ E-mail: marjan.simenc@pei.si 
resumen

\section{la posición del tercer sujeto}

Este artículo se refiere a la distinción hecha por Biesta entre dos posiciones del sujeto que están relacionadas a lo que la Filosofía con Niños es, o puede ser. El autor del presente texto pretende demostrar - refiriéndose a una práctica filosófica diferente, el café filosófico- que una tercera posición del sujeto puede ser encontrada en las prácticas de Filosofía con Niños. Dos formas de esta práctica pueden ser descriptas como las perspectivas argumentativa y hermenéutica de conducir el diálogo filosófico. La interpretación argumentativa considera el elemento filosófico de los cafés filosóficos basándose en el método filosófico determinado por tres competencias filosóficas fundamentales. Lo que es característico de la posición del tercer sujeto es la inclusión del sujeto en el mundo que cambia el propio mundo. Éste ya no es un mundo observado a la distancia por el sujeto, sino un mundo que determina escencialmente el sujeto. A pesar que la posición del tercer sujeto puede ser defendida como derivada de la primera, es aún relevante para pensar la Filosofía con Niños. Por un lado ella destaca la diversidad y la complejidad de las prácticas de Filosofía con Niños y, por otro, levanta la cuestión de la relación entre el primero y el segundo sujeto, por referirse al significado del propio concepto de mundo.

palabras clave: filosofía para niños; posición del sujeto; conocimiento. 
the third subject position

\section{the two subject positions}

Biesta's reflection on PWC can be viewed as a realm delineated by two subject positions. The first position entails a focus on questioning, argumentation and critical thinking. According to Biesta, this position also includes the conveyance of knowledge and skills, as it is based on a subject who is trying to understand and thereby appropriate the world. This is a subject who questions but is never subject to questioning himself.

Biesta considers this position to be significant, yet insufficient. It is perhaps worth noting that the practice of PWC viewed in these terms already exceeds the position for which PWC has traditionally been criticised, claiming that PWC consists merely in children voicing their opinions without any follow-up in the form of analysis and argumentation that PWC remained at the level of doxa without ever rising to episteme (cf. BRENFIER, 2007). From this point of view, it appears that Biesta presents the practice - or one of the aspects of the practice of PWC - in the best possible light.

The second subject position is the position of a subject who does not question but is only addressed and only establishes himself as a subject in response to being addressed. It is this position that offers an opportunity for the consideration of alternative goals of PWC.

However, it appears that the practice of PWC can also be seen as relating to a third subject position. In terms of the differentiation between the egocentric and the Levinasian subject, this third position might not be an entirely new position (cf. BIESTA, 2016) but it is nevertheless worth considering; particularly because the complex position of the teacher in the classroom is easier to consider when approached using multiple definitions. (It appears that Biesta's definition (cf. BIESTA, 2009) of the threefold objective of education consisting of socializationqualification-subjectification/emancipation also points to the complexity of this 
position.). ${ }^{2}$ The simplest way to introduce the third subject position is by referring to the leading metaphor of the article, i.e. the vacuum cleaner.

\section{the robot vacuum cleaner and the status of ignorance}

The leading metaphor of the text is the image of a robot vacuum cleaner. Biesta introduces this metaphor in order to highlight the similarity between the contemporary (constructivist) theories of learning and the independent/autonomous learning of a programmed machine that is gradually able to find its way around a room in and becomes more efficient in its operation. ${ }^{3}$

The robot vacuum cleaner is self-sufficient. It is able to learn on its own how best to navigate a room, so as to vacuum efficiently; if it runs out of power, it makes its way to the charging station. However, there is a problem it cannot (yet) solve and this problem is related to content. Once the robot vacuum cleaner is full, it needs a person to empty it, since the prerequisite for its effective operation is an empty dust bin.

In this sense, the image of the vacuum cleaner resembles the Zen story about the master and a researcher from Europe. The master offers his guest who has come to learn about Zen a cup of tea. He pours the tea until the cup is full to the brim and keeps on pouring, the tea overflowing and spilling on the table. The visitor can no longer restrain himself and blurts: "Be careful, can't you see the cup is full?" The master responds: "Like this cup, you are full of your own opinions and prejudices. How can I show you Zen unless you first empty your cup?"

\footnotetext{
2 This also seems to be Meirieu's position: »The school must transmit, indissociably, (1) knowledge that inscribes the child into a group of belonging and allows it to integrate into it; (2) knowledge that gives the child the means to escape any form of hold, including the hold of the community in which it is inscribed; and (3) knowledge that enables the child to gain access to the universality of the human condition, beyond any specific belonging and beyond legitimate expression of its singularity." (MEIRIEU, 2002, p. 35)

3 This comparison between a robot vacuum cleaner and education can also serve as a (critical) illustration of the theory to which the constructivist theory of learning is trying to respond, namely the bucket/banking model of learning. In this context, the vacuum cleaner refers to the pupils who are expected to ingest all sorts of knowledge provided to them by the education system. This very illustration of the model also incorporates its criticism, since the vacuum cleaner does not hoover up the best achievements of the human mind but filth that needs to be removed as quickly and as discreetly as possible (a robot vacuum cleaner being the closes thing to a an invisible filth remover). The vacuum cleaner model therefore also suggests that what children learn in school is not essential but rather irrelevant and superfluous.
} 
The vacuum cleaner model thus also demonstrates that pupils particularly those who have been in the education system for some time - are in a way full. Meanwhile, it is assumed of children participating in PWC that they have the capacity for being empty - that is for not-knowing. The ignorance that is a prerequisite for questioning (teaching children to ask better question is one commonly accepted quality of PWC) allows for a critical distance from knowledge and a reflection of knowledge. Perhaps one of the aims of PWC is to help pupils to create or find a void within them that will allow them to distance themselves from opinions, beliefs, prejudices, creeds and fragments of discourse they have accumulated, thus generating a space where their world can become a subject of ignorance.

This element of an (empty) void, a perplexity, a discontinuation of understanding points to a possible connection between the two subject positions referred to by Biesta. What is characteristic of both the second subject position as well as certain aspects of the first subject position is a specific ignorance. The difference might be that the second subject position seems to imply a distance from knowledge in general, while the first can be seen as referring to a specific void in knowledge. But such a comparison between the two positions is premature. Defining the relationship between the two positions will be easier once a distinction is established within the first position as can be seen in the community of inquiry, i.e. in the practice of PWC. The best way to illustrate this distinction is by referring to a different philosophical practice, namely the philosophy café.

\section{the third position, the third element}

The philosophical practice known as the philosophy café was initiated in 1992 by Marc Sautet in the Paris coffee house Café des Phares at the Place de la Bastille. Two interpretations of this practice have arisen in France that could be described as the argumentative and the hermeneutic approach to conducting a philosophical dialogue. The argumentative interpretation considers the philosophical element of philosophy cafés to lie in following the philosophical method which is based on an understanding of philosophical thinking as being 
determined by three fundamental philosophical competences: problematization, conceptualisation and argumentation. (cf. TOZZI, 2001) Ultimately, the aim of philosophy cafés is arriving at an answer to the initial question, but it is the method that matters.

Gunter Gorhan (cf. GORHAN, 2004) sees things slightly differently, making a distinction between three types of discussions in philosophy cafés. In responding to the initial question, the first type is based on a clash of views, exchanging arguments and counter-arguments until the strongest argument prevails. The aim of the debate is consensus regarding the best view which resulted from the argumentation. The second debate model is the »debate as construction«. Participants in the debate do not compete with one another, but work together in order to build something. A moderator coordinates the exchange of ideas and helps the participants rise above their individual views so as to form a universal and common view. This appears to be a continuation of the first type of discussion, the only difference being that the final objective of the debate is considered as a common goal from the outset. The key feature of the philosophy café is no longer the competition among participants, but rather cooperation where everyone contributes to a process that leads to a common result.

Finally, the third debate type is the »debate as (trans)formation«. As suggested by the name, its aim is a (trans)formation of the participants. Since the subject of inquiry is mankind as such, there is no more distinction between the subject and the object. Listening to others and their understanding enriches my »internal dialogue«, which is something quite different from honing and mastering arguments that will support my view. It appears as if the tissue of my being is partly woven from this symbolic reality. When I think about this reality together with others, an internal dynamic is established which affects my being. By listening to others in such a conversation, I am able to listen to myself and hear the waves that their discourse triggers within me.

Gorhan explains the difference between the two approaches to the philosophical café by referring to the quest for personal meaning: 
We, the disillusioned (or simply disenchanted, dis-fascinated by the given, imposed meaning and therefore free to actually give the world back its charm) people of the postmodernity must give a sense, must create a meaning that can guide our individual and collective existence. [...] Man, this 'unfixed animal' (Nietzsche) open to its own transcendence - insofar as he has not resigned and become reduced to mere mechanics, albeit extremely sophisticated, but still 'final', stabilised - will always have to revisit the question of meaning. To put it differently: man, insofar as he is not 'fixed' but remains human, must ensure that the meaning of his being and his existence remain an outstanding issue. (GORHAN, 2006, p. 5).

Instead of seeking to transcend subjectivity, subjectivity must be maintained. What is pursued is an answer that will not eliminate the question, but preserve it. The exchange of ideas among subjects aims at producing an »event of meaning «. Key elements of the discussion are keeping things slow, allowing for silence and preventing argument duels. What is at the forefront is listening in search of fundamental values that motivate the participants' interventions; emotional engagement and helping speakers to articulate their ideas in a language that is understandable for others. It is the event of meaning that is the focus of attention; the unexpected connections, the extraordinary, the unforeseen, the unplanned. The main objective of the proceedings in a philosophy café is thus a philosophical conversion, a formation and transformation of subjectivity. It is all about the openness that creates a space for the emergence of meaning and every answer is merely temporary, provisional, since each individual is himself responsible for the meaning of his life. There is a strong existential element and an effort to preserve subjectivity as a realm of freedom and responsibility.

The position of the subject in the existential quest for meaning is not the position of a master controlling the world; it is a much weaker position of somebody who is embedded in the world and is substantially defined by the heterogeneous elements of this world (habits, norms, practices, stories, discourses). This is a subject trying to find his bearings in this world, but being intertwined with it, determined by it and embedded in it and because his understanding is defined by a horizon he is unable to fully comprehend, he can never be the master of meaning. 
Hence, what is characteristic of the third subject position is embeddedness in the world which in turn changes the world itself. This is no longer a world observed by the subject from a distance but a world which essentially determines the subject. Comparing this world to the concept of the world in Biesta's article, a significant difference comes to light: "Existing as subject is therefore not something that occurs in a vacuum; it necessarily occurs in the world, natural and social. The world, however, should not be understood as a context or backdrop, but is what we encounter when we take initiatives, when we initiate something. The world first and foremost appears in the way in which it offers resistance quite literally - to our initiatives". (BIESTA, 2017, p. 429).

If it is the world that offers resistance to the subject, this resistance actually occurs on the basis of (erroneous) interpretations or failed actions in the world resulting from such (implicit) interpretations. When experiencing resistance from the world, the world (at least for the subject) splits itself into a world in which the subject feels at home and the strange part which is resisting being subsumed in this world. It could be said that this split introduces a third element in the relationship between the subject and the (part of the) world offering resistance to the subject - this element could be called the symbolic universe.

I consider this third element to be significant: reflecting upon my experience as a teacher I inevitably find myself faced with a dimension of reality which would encompass what is usually referred to as knowledge, tradition, Popper's third world - i.e. what can be described in very simplistic and risky terms as a product (of society) which exists independently of the subject. This element seems to be related to the subject position, since the "subject" of the subject position presupposes a social practice (discourse, symbolic structure) that constitutes its position. It appears to me that the position of the teacher is inextricably linked to a specific attitude towards knowledge. The question how to conceptualise this relation is not only relevant to Biesta's article: PWC itself has a complex attitude towards philosophical knowledge, sometimes both affirming and rejecting the importance of philosophical tradition at the same time. On the 
one hand, it is unwaveringly committed to the independent thinking of children and openness to what they can bring to the world; yet on the other hand, the interpretations and conceptualizations of PWC »events « as a rule follow the »models of thinking « established in the philosophical tradition. ${ }^{4}$

\section{references}

BIESTA, G. Good education in an age of measurement: on the need to reconnect with the question of purpose in education. Educational Assessment, Evaluation and Accountability, (21)1, 2009, p. 22-46.

BIESTA, G. Who's Afraid of Teaching? Heidegger and the Question of Education ('Bildung'/'Erziehung'). Educational Philosophy and Theory, (48) 8, 2016, p. 832-845. BIESTA, G. Touching the soul? Exploring an alternative outlook for philosophical work with children and young people, childhood \& philosophy. Childhood E Philosophy. (13) 28, 2017, p. 415-452.

GORHAN, G. Café philo: Quelle 'méthode' pour quel ‘débat'? Diotime, 21, 2004.

GORHAN, G. Debattre pour donner le sens. Diotime, 29, 2006.

MEIRIEU, P. Transmettre, oui... mais comment? Sciences Humaines, Hors-serie (36). 2002. SHARP, A. M., \& REED, R. (Eds.). Studies in Philosophy for Chidren. Philadelphia, PA: Temple University Press, 1992.

TOZZI, M. (2001). Le café-philo: quelle responsabilité pour le philosophe. Diotime,12.

received in: 12.08 .2017

accepted in: 26.08.2017

\footnotetext{
${ }^{4}$ When philosophical tradition is concerned, there seems to be a difference between PWC and P4C. The introduction to Studies in Philosophy for children begins with establishing a link between history of philosophy P4C: »Philosophy for children is an attempt to reconstruct and present the history of philosophy in such a way that children can appropriate it for themselves so as to reason well in a self-correcting manner.«(SHARP; REED, 1992, p. xiii)
} 